\title{
Manajemen Pendidikan Karakter Dalam Meningkatkan Disiplin Peserta Didik
}

\author{
Imam Hambali \\ Institut Agama Islam (IAI) Al-Azhaar Lubuklinggau \\ E-mail: imamhambali1873@yahoo.com
}

\begin{tabular}{l}
\hline Article Info \\
\hline Article History \\
Received: $2021-01-12$ \\
Revised: 2021-02-01 \\
Published: $2021-02-06$
\end{tabular}

Keywords:

Management;

Character;

Discipline.

\begin{abstract}
This study is to determine the planning, implementation, evaluation, obstacles, and solutions to face the barriers of character education in improving students' disciplinary attitudes. Data collection techniques used were observation, interviews, and documentation. Data were analyzed using data reduction, data presentation, and drawing conclusions. The technique of checking the validity of the data is by means of triangulation of sources and techniques. The results of this study indicate that the character education management that is carried out can be seen by the existence of measurable programs and activities in educational institutions that refer to the interests of the quality of graduates through the implementation of good management. From the management of the school, it has an impact on character education in increasing the disciplinary attitude of students. However, the facts in the field are still not optimal and the results are not as expected by all parties. This is due to the existence of several factors that are indicated as obstacles, both internal and external. So that educational institutions continue to improve themselves in carrying out character education programs for students. The solution taken in improving the disciplinary character of students is to build synergy of all parties in the education community to build a culture of discipline in school life. The recommendations given are related to the preparation of program plans and their implementation, which can involve all school stakeholders, so that all elements in school stakeholders know their roles, functions and responsibilities. Furthermore, every implementation of the school's extracurricular activities needs to be evaluated in order to measure the achievement of the goals that have been set and concrete improvement steps in the future.
\end{abstract}

\begin{tabular}{l}
\hline Artikel Info \\
\hline Sejarah Artikel \\
Diterima: 2021-01-12 \\
Direvisi: 2021-02-01 \\
Dipublikasi: 2021-02-06
\end{tabular}
Abstrak

Penelitian ini adalah untuk mengetahui perencanaan, pelaksanaan, evaluasi, hambatan, dan solusi menghadapi hambatan pendidikan karakter dalam meningkatkan sikap disiplin peserta didik. Teknik pengumpulan data yang digunakan adalah observasi, wawancara, dan dokumentasi. Data dianalisis menggunakan reduksi data, peyajian data, dan penarikan kesimpulan. Teknik pemeriksaan keabsahan data dengan triangulasi sumber dan teknik. Hasil penelitian ini menunjukkan bahwa manajemen pendidikan karakter yang dijalankan terlihat dengan adanya program yang terukur dan kegiatan yang ada dalam lembaga pendidikan mengacu pada kepentingan mutu lulusan melalui implementasi manajemen yang baik. Dari pengelolaan sekolah tersebut, berdampak kepada pendidikan karakter dalam meningkatkan sikap disiplin peserta didik. Namun fakta di lapangan hal tersebut masih belum optimal dan hasilnya belum sesuai dengan yang diharapkan semua pihak. Hal ini di sebabkan adanya beberapa faktor yang di indikasikan sebagai penghambat, baik bersifat internal maupun eksternal. Sehingga lembaga pendidikan terus berbenah diri dalam menyelenggarakan program pendidikan karakter pada peserta didik. Solusi yang dilakukan dalam meningkatkan karakter disiplin peserta didik adalah dengan membangun sinergi semua pihak dalam masyarakat pendidikan untuk membangun budaya disiplin dalam kehidupan Sekolah. Rekomendasi yang diberikan adalah terkait penyusunan rencana program dan pelaksanaanya dapat dilakukan melibatkan semua stakeholders sekolah, sehingga semua elemen dalam stakeholders sekolah mengetahui peran, fungsi serta tanggung jawabnya. Selanjutnya setiap pelaksanaan kegiatan ekstrakurikuler sekolah tersebut perlu di evaluasi dalam rangka mengukur ketercapaian tujuan yang telah ditetapkan dan langkah-langkah perbaikan yang konkret ke depan. 


\section{PENDAHULUAN}

Pada era revolusi industri seperti saat ini, masalah pendidikan merupakan suatu hal yang sangat penting. Pendidikan merupakan kebutuhan yang sangat penting bagi setiap orang dalam rangka mengembangkan potensi diri, kecerdasan, keterampilan dan dapat membentuk kepribadian. Dengan pendidikan diharapkan seseorang dapat menggali informasi atau pengetahuan, melatih setiap bakatnya agar semakin terampil dan berkembang karakter pribadi seseorang. Peran pendidikan sangat strategis dalam upaya membangun generasi atau peserta didik yang berkualitas terutama dalam aspek karakter.

Indonesia membutuhkan sumber daya manusia dalam jumlah dan mutu yang memadai sebagai pendukung utama pembangunan. Untuk memenuhi sumber daya manusia tersebut, pendidikan memiliki peran sangat penting,karena di era globalisasi dan bergulirnya masyarakat ekonomi Asean, Indonesia dituntut untuk menghasilkan sumber daya yang unggul untuk mampu bersaing. Persaingan akan sangat berat jika bangsa ini minim dengan kualitas dan sangat sulit untuk menjadi bangsa yang kompetitif dan berkualitas.

Berdasar Undang-Undang Sisdiknas No. 20 Tahun 2003 menyatakan bahwa Pendidikan adalah usaha sadar dan terencana untuk mewujudkan suasana belajar dan proses pembelajaran agar peserta didik secara aktif mengembangkan potensi dirinya untuk memiliki kekuatan spiritual keagamaan, pengendalian diri, kepribadian, kecerdasan, karakter mulia, serta keterampilan yang diperlukan dirinya, masyarakat, bangsa dan negara.

Pendidikan nasional bertujuan untuk mengembangkan segala potensi peserta didik agar menjadi manusia yang beriman dan bertaqwa kepada Tuhan yang Maha esa, berkarakter mulia, sehat, berilmu, cakap, kreatif, mandiri dan menjadi warga negara yang demokratis serta tanggungjawab. Berdasarkan fungsi dan tujuan pendidikan nasional tersebut,jelas bahwa pendidikan harus diselenggarakan secara sistematis guna mencapai tujuan tersebut.

Pelaksanaan kegiatan intrakurikuler di Sekolah Menengah Umum berdasarkan pada Peraturan Perundang-Undangan Nomor 20 Tahun 2003 tentang Sistem Pendidikan Nasional dan Peraturan Pemerintah Republik indonesia Nomor 19 Tahun 2005 tentang Standar Nasional Pendidikan, yang mengamanatkan bahwa Kurikulum disusun oleh satuan pendidikan dengan mengacu kepada kurikulum nasional serta berpedoman pada panduan yang disusun oleh Badan Standar Nasional Pendidikan (BNSP).

Rusdi (2010: 68) mengemukakan bahwa Kegiatan intrakurikuler bertujuan untuk menumbuhkan kemampuan akademik siswa. Kegiatan kokurikuler dimaksudkan untuk lebih memahami materi pengajaran yang telah dipelajari pada kegiatan intrakurikuler di kelas. Kegiatan ekstrakurikuler membantu dalam pengembangan aspek-aspek seperti minat, bakat dan kepribadian. Tiga kegiatan tersebut merupakan kegiatan yang diikuti anak sehari-harinya. Sedangkan menurut Kunandar (2007: 177) yang dimaksud dengan kegiatan intrakurikuler merupakan kegiatan pengembangan diri yang dilaksanakan sebagian besar di dalam kelas (intrakurikuler). Kegiatan intrakurikuler ini tidak terlepas dari proses belajar mengajar yang merupakan proses inti yang terjadi di sekolah sebagai suatu lembaga pendidikan formal. Berdasarkan hal tersebut, belajar diartikan sebagai suatu bentuk pertumbuhan atau perubahan dalam diri seseorang yang dinyatakan dalam cara-cara bertingkah laku yang baru berkat pengalaman dan latihan.

Berdasar Permendikbud No. 62 tahun 2014 tentang ekstrakurikuler pada pendidikan dasar \& menengah dinyatakan bahwa Kegiatan kurikuler yang dilakukan oleh peserta didik diluar jam belajar kegiatan intrakurikuler dan kegiatan kokurikuler, dibawah bimbingan dan pengawasan satuan pendidikan. Kegiatan ekstrakurikuler diselenggarakan dengan tujuan untuk mengembangkan potensi, bakat, minat, kemampuan, kepribadian, kerjasama dan kemandirian peserta didik secara optimal dalam rangka mendukung pencapaian tujuan pendidikan nasional.

Adapun jenis kegiatan ekstrakurikuler yang diprogramkan di sekolah dijelaskan Departemen Pendidikan dan Kebudayaan (1995: 3) sebagai berikut : 1) Pendidikan Kepramukaan, 2) Pasukan Pengibar Bendera (PASKIBRA), 3) Palang Merah Remaja (PMR), 4) Pasukan Keaman Sekolah (PKS), 5) Gema Pencinta Alam, 6) Filateli, 7) Koperasi Sekolah, 8) Usaha Kesehatan Sekolah (UKS), 9) Kelompok Ilmiah Remaja (KIR), 10) Olahraga, dan 11) Kesenian. Dalam setiap kegiatan yang dilakukan, pasti tidak lepas dari aspek tujuan. Kerena suatu kegiatan yang diakukan tanpa jelas tujuannya, maka kegiatan itu akan sia-sia. Begitu pula dengan kegiatan intrakurikuler dan ekstrakurikuler tertentu memiliki tujuan tertentu. Kegiatan-kegiatan ini memiliki tujuan bukan hanya melahirkan peserta didik yang memiliki kompetensi tetapi juga diharapkan dapat menghasilkan peserta didik yang memiliki karakter. Namun pelaksanaan kegiatan intrakurikuler dan ekstrakurikuler belum mampu meningkatkan karakter peserta didik, secara khusus karakter disiplin peserta didik. Hal ini terjadi karena proses penyelenggaraan intrakurikuler sudah sangat padat dengan kegiatan pembelajaran sehingga dalam pembinaan karakter peserta didik kurang mendapatkan waktu terintegrasi dengan proses pembelajara. Sedangkan dalam penyelenggaraan ekstrakurikuler lebih menekankan pada penyediaan kegiatan-kegiatan untuk peserta dan meraih prestasi pada bidang olahraga sehingga pembinaan karakter tidak maksimal dalam penyelenggaraan ekstrakurikuler.

Pendidikan dewasa ini dituntut untuk dapat merubah peserta didik ke arah yang lebih baik. Oleh karena itu, Kementrian Pendidikan Nasional telah 
merumuskan 18 karakter bangsa. Kemudian jenisjenis karakter bangsa menurut Kementrian Pendidikan Nasional dalam Suyadi (2013:97) diantaranya adalah Religius, Jujur, Toleransi, Disiplin, Kerja keras, Kreatif, Mandiri, Demokratis, Rasa ingin tahu, Semangat kebangsaan, Cinta tanah air, Menghargai prestasi, Bersahabat, Cinta damai, Gemar membaca, Peduli lingkungan, Peduli sosial dan Tanggung jawab.

Peserta didik diharapkan dapat memanfaatkan pendidikan kepribadian serta mengaitkan pengetahuan yang diperolehnya dalam program akademik pada kegiatan intrakurikuler dengan tuntutan kebutuhan dan keadaan lingkungan. Sedangkan dalam kegiatan ekstrakurikuler banyak jenisnya, karena berkaitan dengan minat dan bakat siswa selain dari kegiatan inti. Dengan kegiatan ekstrakurikuler yang ada, siswa dapat memilih kegiatan yang sesuai dengan kemampuan dan minat masing-masing. Menurut Requene (2005:122) menjelaskan bahwa Disiplin adalah sikap atau tindakan yang menunjukan perilaku tertib dan patuh pada berbagai ketentuan dan peraturan. Disiplin berasal dari bahasa latin Discere yang berarti belajar. Dari kata ini timbul kata Disciplina yang berarti pengajaran atau pelatihan. Disiplin berasal dari bahasa Inggris yaitu "disciple" yang berarti pengikut atau murid. Kemudian menurut Prijadaminto (2004:56) "Disiplin adalah suatu kondisi yang tercipta dan terbentuk melalui proses dari serangkaian perilaku yang menunjukan nilai-nilai ketaatan pada Tuhan, keteraturan, dan ketertiban dalm memperoleh ilmu". Sedangkan Kadir (1994:80) mendefinisikan "disiplin adalah kepatuhan terhadap peraturan atau tunduk pada pengawasan atau pengendalian. Kedua disiplin yang bertujuan mengembangkan watak agar dapat mengendalikan diri, agar berperilaku tertib dan efisien".

Disiplin mempunyai peranan yang sangat penting dalam mencapai tujuan pendidikan. Berkualitas atau tidaknya pembelajaran peserta didik sangat dipengaruhi oleh faktor yang paling pokok yaitu kedisiplinan, disamping faktor lingkungan baik keluarga, sekolah, dan masyarakat. Disiplin bagi peserta didik adalah hal yang rumit dipelajari karena merupakan hal yang kompleks dan banyak kaitannya, yaitu terkait dengan pengetahuan (kognitif), sikap (afektif), dan perilaku (psikomotorik). Masalah disiplin yang dibahas dalam penelitian ini adalah disiplin yang menjadi hasil dari kegiatan ekstrakurikuler yang menjadi suplemen pendidikan karakter.

Pendidikan karakter sangat dibutuhkan oleh semua bangsa karena merupakan bagian penting dalam membangun jati diri sebuah bangsa. Lahirnya pendidikan karakter yang menekankan dimensi etisspiritual dalam proses pembentukan pribadi peserta didik. Lickona dalam bukunya yang berjudul, Educating for character (1991), (Irawan, 2010:59) menyimpulkan bahwa Pendidikan karakter adalah usaha sengaja untuk menolong orang agar memahami, peduli akan, dan bertindak atas dasar inti nilai-nilai etis. Ia menegaskan bahwa tatkala kita berfikir tentang bentuk karakter yang ingin ditunjukkan oleh anak-anak, teramat jelas bahwa kita menghendaki mereka mampu menilai apa yang benar, peduli tentang apa yang benar, serta melakukakn apa yang di yakininya benar, bahkan ketika harus menghadapi tekanan dari luar dan godaam dari dalam. Dalam ikhtiar itu, para siswa bisa menidentifikasi perilakunya dengan watak orang yang ditokohkan. Oleh karena itu, hakikat pendidikan karakter dalam konteks pendidikan adalah pendidikan nilai, yaitu pendidikan nilai-nilai luhur yang bersumber dari budaya bangsa Indonesia itu sendiri, yang bertujuan membina karakter genrerasi muda. Isntitusi pendidikan yang terdiri dari sekolah/madrasah, keluarga dan lingkungan sosial, harus menjadi teladan atau modelling bagi proses pembelajaran dan pendidikan peserta didik. Hal tersebut disebabkan praktik pendidikan di setiap jenjangnya bukan sekedar pengembangan nalar peserta didik, tetapi juga adalah pembentukan karakter dan akal yang berbudi.

Pembentukan karakter dalam diri seseorang merupakan fungsi dari seluruh potensi individu (kognitif, afektif, konatif dan psikomotorik). Menurut Lewin dalam Andersen (1980:89) bahwa : Perilaku seseorang merupakan fungsi dari watak yang terdiri atas kognitif, afektif dan psikomotorik dan karakteristik lingkungan saat perilaku tau perbuatan di tampilkan. Perilaku merupakan bagian ranah afektif berkaitan dengan ranah lainnya. Namun bila di telaah, ke dalam tiga ranah tersebut untuk tiap peserta didik tidak sama. Ada peserta didik yang memiliki penalaran tinggi tetapi tidak terampil dan ada yang rajin, ramah, mudah bergaul dan penalarannya biasa. Hal ini menjadi karkteristik setiap peserta didik atau potensi peserta didik. Potensi yang dimiliki oleh peserta didik harus di kembangkan menjadi kemampuan untuk hidup di masyarakat.

Realisasi pendidikan karakter perlu diwujudkan dalam keluarga, masyarakat atau lingkungan dan sekolah. Oleh karena itu, secara otomatis pendidikan karakter di sekolah perlu didukung oleh orang tua dan masyarakat. Ini disebabkan karena ketiga komponen tersebut secara komplementer saling memberikan pendidikan karakter pada peserta didik. Sekolah sebagai suatu lembaga formal perlu mengambil peran dalam pengembangan sisi afektif peserta didik. Dengan kata lain, dalam pelaksanaan pendidikan karakter, sekolah perlu menekankan pada pembinaan perilaku peserta didik, sebab karakter pada dasarnya bukan penguasaan pengetahuan tetapi lebih banyak pada aspek afektif. Apa yang berlaku di sekolah formal sampai saat ini, dalam pembelajaran karakter belum menyentuh aspek afektif ini.

Pendidikan karakter penelitian ini, difokuskan pada kedisiplinan. Menurut Jahiri (2004:79) disiplin ialah tuntunan mengenai apa yang baik, benar dan adil. Sedangkan menurut Endang Sumantri disiplin adalah sesuatu yang berharga, yang penting dan 
berguna serta menyenangkan dalam kehidupan manusia yang dipengaruhi pengetahuan dan sikap yang ada pada diri atau hati nuraninya. Sehingga dapat disimpulkan bahwa disiplin adalah segala sesuatu yang baik dan dianggap berharga.

Berdasarkan masalah-masalah ini perlu dilakukan penelitian lebih lanjut supaya dapat di temukan data yang valid dan sekaligus dapat ditentukan alternatif pemecahannya. Sehingga penulis mengangkat judul "Manajemen pendidikan karakter untuk meningkatkan disiplin peserta didik".

\section{METODE PENELITIAN}

Penelitian ini menggunakan pendekatan kualitatif, menurut (Yaniawati, 2017) pendekatan kualitatif yaitu penelitian yang diarahkan untuk pencapaian tujuan memperoleh penjelasan secara mendalam atas penerapan sebuah teori. Penelitian kualitatif memiliki karakteristik analisis tekstual atau dalam pandangan (Creswell, 2017) penelitian kualitatif merupakan penelitian interpretatif, yang di dalamnya peneliti terlibat dalam pengalaman yang berkelanjutan dan terus menerus dengan para partisipan. Adapun metode dalam penelitian ini adalah deskriptif analisis. Metode ini menurut (Ratna, 2011) dilakukan dengan cara mendeskripsikan kata-kata yang kemudian disusul dengan analisis dan pada umumnya untuk memaknai data yang berupa teks atau gambar.

Dalam hal pengumpulan data yang diperoleh dari berbagai sumber, latar, dan beragam cara pada penelitian ini adalah melalui studi kepustakaan. Studi kepustakaan merupakan langkah awal dalam metode pengumpulan data. Studi pustaka merupakan metode pengumpulan data yang diarahkan kepada pencarian data dan informasi melalui dokumen-dokumen, baik dokumen tertulis, foto-foto, gambar, maupun dokumen elektronik yang dapat mendukung dalam proses penulisan. Menurut (Sugiyono, 2015), dokumen merupakan catatan peristiwa yang sudah berlalu. Dokumen bisa berbentuk gambar tulisan, gambar, atau karya-karya monumental dari seseorang. Hal itu, sejalan dengan pendapat (Creswell, 2017) bahwa dokumen-dokumen kualitatif (qualitatif document) bisa berupa dokumen publik (misalnya koran, makalah, laporan kantor) ataupun dokumen privat (mislanya buku harian, diari, surat, e-mail).

\section{HASIL DAN PEMBAHASAN}

Berdasarkan hasil penelitian bahwa manajemen pendidikan karakter untuk meningkatkan disiplin peserta didik belum optimal dilakukan sesuai tahapan manajemen pendidikan. Sekolah belum mampu mengoptimalkan fungsi-fungsi manajemen pendidikan karakter dalam kegiatan ekstrakurikuler yang mencakup perencanaan, pelaksanaan dan evaluasi. Kaitan dengan hal ini Judith (Syafrudin, 2002:109) mengemukakan,"manajemen sekolah mencakup perencanaan, pengorganisasian, pelaksanaan, dan pengawasan." Kemudian Umaedi (1999:3) menyebutkan proses pengelolaan sekolah mencakup 4 tahapan, yaitu: "perencanaan (planning), mengorganisasikan (organizing), pengarahan (actuating), dan pengawasan (controlling)". Pendapat tersebut menjelaskan, bahwa manajemen sekolah merupakan sebuah proses yang terdiri dari tahapantahapan dimulai dari perencanaan, pengorganisasian, pengarahan, dan pengawasan. Demikian juga, dalam manajemen terkandung pula pemanfaatan sumber daya yang ada untuk mencapai tujuan pendidikan atau sekolah sesuai visi dan misi sekolah.

Sumber daya yang terkandung dalam manajemen, yaitu manusia, bahan, sarana dan prasarana, metode, pembiaayaan, dan informasi. Sumber daya bersifat terbatas, sehingga tugas manajer dalam hal ini kepala sekolah harus dapat mengelola keterbatasan sumber daya tersebut secara efektif dan efisien untu mencapai sasarannya, baik tujuan programnya maupun organisasi secara umum. Dalam perencanaan pendidikan karakter untuk meningkatkan disiplin peserta didik, sekolah telah merumuskan program kerja yang secara umum telah di masukkan dalam RKS dan program kerja ekstrakurikuler secara khusus. Penyusunan rencana program tersebut dilakukan setiap awal tahun pelajaran dengan melibatkan stakeholder, sekolah sesuai tugas pokok dan kewenangannya.

Adapun yang menjadi dasar dalam penyusunan program kerja sekolah, yaitu visi, misi dan tujuan sekolah serta peraturan perundang-undangan yang terkait dengan pendidikan. Sedangan penyusunan program kerja kegiatan ekstrakurikuler dengan berlandaskan kepada peraturan perundang-undangan yang terkait yang mengatur semua kegiatan ekstrakurikuler dan program kerja sekolah secara khusus. Menurut Dauglass (Nurdin, 2009:233) yang merumuskan lima prinsif manajemen pendidikan, diantaranya sebagai berikut : a) Memprioritaskan tujuan di atas kepentingan pribadi dan kepentingan mekanisme kerja, b) Mengkoordinasikan wewenang dan tanggung jawab, c) Memberi tanggung jawab kepada personil hendaknya sesuai dengan sifat-sifat dan kemampuannya, d) Mengenal secara baik faktorfaktor psikologis manusia, dan e) Memperhatikan nilai-nilai dalam organisasi.

Pendapat di atas dapat dijadikan acuan dalam penyusunan rencana program sekolah untuk mencapai tujuannya. Hal tersebut berdasarkan asumsi bahwa manajemen pendidikan merupakan proses penggunaan sumber daya (baik sumber daya manusia maupun non manusia) secara efektif dan efisien untuk mencapai tujuan pendidikan melalui fungsi perencanaan, pengorganisasian, pelaksanaan, serta pengawasan. Dalam pengelolaan pendidikan, menurut Rohiat (2009:21) terdapat 7 (tujuh) garapan manajemen yaitu : a) Manajemen kurikulum, b) Manajemen kesiswaan, c) Manajemen personil/ anggota, d) Manajemen sarana dan prasarana, e) Manajemen keuangan, f) Manajemen hubungan sekolah dan masyarakat, dan g) Manajemen layanan khusus. Begitu pula dengan manajemen pendidikan karakter untuk meningkatkan disiplin peserta didik 
pada tingkat satuan pendidikan (SMA) harus memperhatikan semua unsur manajemen tersebut. Secara khusus, Mulyasa (2002:22) mengemukakan upaya peningkatan kualitas pendidikan harus dimulai dengan pembenahan sekolah, disamping peningkatan mutu kualitas guru dan pengembangan sumber belajar.

Selanjutnya Mulyasa (2014:14) menyebutkan jurus pertama yang harus diperhatikan dalam menyukseskan pendidikan karakter di sekolah adalah memahami hakikat pendidikan karakter dengan baik, Dengan demikian keberhasilan penyelenggaraan pendidikan karakter di sekolah yang efektif dan efisien dapat tercapai sesuai rencana, jika didukung dengan pendekatan manajemen sekolah yang baik. Oleh karena itu, dalam pelaksanaan pendidikan karakter, kepala sekolah memiliki peran penting sebagai manajer dalam menentukan arah keberhasilan, baik dalam mencapai tujuan organisasi secara khusus maupun tujuan pendidikan nasional secara umumnya, termasuk pelaksanaan kegiatan ekstrakurikuler dalam membina karakter disiplin dan bertanggung jawab.

Agar pelaksanaan manajemen pendidikan karakter untuk meningkatkan disiplin peserta didik tersebut mencapai tujuan sesuai rencana program yang telah dirumuskan sekolah, maka manajemen terpadu sekolah harus memfokuskan pada peningkatan kualitasnya. Kualitas yang dimaksud adalah sekolah sebagai lembaga pendidikan dalam pengelolaanya dapat memberikan layanan yang maksimal dan menjadikan peserta didiknya sebagai lulusan sesuai dengan tujuan pendidikan.

Hal ini memiliki relevansi dengan pendapat Ali (2007:621) yang mengemukakan Manajemen mutu itu sendiri pada hakekatnya menggambarkan kepada semua aktivitas dari fungsi manajemen secara keseluruhan, mulai dari perencanaan, pengorganisasian, pengendalian hingga kepemimpinan, yang menentukan kebijakan mutu, tujuan dan tanggung jawab serta implementasinya melalui alat-alat manajemen, seperti perencanaan, pengendalian, penjaminan dan peningkatan mutu. Dengan demikian bahwa manajemen mutu sekolah merupakan segala aktivitas sekolah dengan menjalankan semua fungsifungsi manajemen secara sistemik yang dimulai dari tahapan perencanaan, pengorganisasian, pelaksanaan dan pengendalian dalam mencapai visi dan misi yang telah ditentukan. Dalam hal ini, Ali (2007:619) menjelaskan, "pendidikan bermutu adalah dambaan serta harapan setiap orang ataupun lembaga". Adapun indikator-indikator menurut Mulyasa (2002:84-85) adalah sebagai berikut : a) Indikator input: indikator ini meliputi karakteristik guru, fasilitas, perlengkapan, dan materi pendidikan serta kapasitas manajemen. b) Indikator process: indikator ini meliputi perilaku administratif, alokasi waktu guru dan alokasi waktu peserta didik. c) Indikator ouput: indikator dari output ini berupa hasil-hasil dalam bentuk perolehan peserta didik dan dinamikanya sistem sekolah, hasil yang berhubungan dengan prestasi belajar, dan hasil- hasil yang berhubungan dengan perubahan sikap, serta hasil-hasil yang berhubungan dengan keadilan, dan keamanan. d) Indikator outcome: indikator ini meliputi jumlah lulusan ke tingkat pendidikan berikutnya, prestasi belajar di sekolah yang lebih tinggi dan pekerjaan serta pendapatan

Sedangkan berkaitan dengan pelaksanaan pendidikan karakter Mulyasa (2014:17-18) menjelaskan, character Education Quality Standards merekomendasikan 11 prinsif untuk mewujudkan pendidikan karakter yang efektif, diantaranya sebagai berikut : a) Mempromosikan nilai-nilai dasar etika sebagai basis karakter, b) Mengidentifikasi karakter secara komprehensif supaya mencakup pemikiran, perasaan, dan perilaku, c) Menggunakan pendekatan yang tajam, proaktif dan efektif untuk membangun karakter, d) Menciptakan komunitas sekolah yang memiliki kepedulian, e) Memberi kesempatan kepada peserta didik untuk menunjukan perilaku yang baik, f) Memiliki cakupan terhadap kurikulum yang bermakna dan menantang yang menghargai semua peserta didik, membangun karakter mereka dan membantu mereka untuk sukses, g) Mengusahakan tumbuhnya motivasi diri dari para peserta didik, h) Memfungsikan seluruh staf sekolah sebagai komunitas moral yang berbagi tanggung jawab untuk pendidikan karakter dan setia kepada nilai dasar yang sama, i) Adanya pembagian kepemimpinan moral dan dukungan luas dalam membangun inisiatif pendidikan karakter, j) Memfungsikan keluarga dan anggota masyarakat sebagai mitra dalam usaha membagun karakter , serta k) Mengevaluasi karakter sekolah, fungsi staf sekolah sebagai guru-guru karakter, dan manifestasi karakter positf dalam kehidupan peserta didik.

Selain dari itu, masyarakat dan orang tua mengharapkan anak-anaknya mendapatkan pendidikan yang bermutu agar mampu bersaing memperoleh berbagai keunggulan dan peluaag di masa yang akan datang, baik dalam meriah pekerjaan, melajutkan ke perguruan tinggi maupun menginternalisasikan kehidupan yang berlandaskan nilai-nilai karakter.

Pelaksanaan pendidikan karakter melalui program ekstrakurikuler diwujudkan sekolah melalui kegiatankegiatan ekstra sesuai dengan pilihan minat dan bakat peserta didik yang ada di sekolah. Adapun masalahmasalah yang dihadapi sekolah, baik dari internal maupun eksternal merupakan suatu hal yang umum, termasuk dalam pelaksanaan manajemen pendidikan karakter untuk meningkatkan disiplin peserta didik. Namun demikian masalah-masalah yang menjadi hambatan dapat dijadikan pihak sekolah sebagai tantangan dan peluang untuk melakukan perbaikanperbaikan ke depan. Upaya tersebut dalam rangka meminimalisir masalah yang muncul sebagai solusi positif kegiatan ekstrakurikuler dalam membina karater peserta didik mengenai karakter disiplin di sekolah. Pendekatan manajemen mutu harus menjadi komitmen sekolah sebagai penyelenggara pendidikan untuk semakin lebih baik memberi pelayanan. 


\section{SIMPULAN DAN SARAN}

\section{A. Simpulan}

Dalam menjalankan fungsi-fungsi manajemen pendidikan tersebut, kepala sekolah sebagai manajer yang bertanggungjawab dalam pengelolaan sekolah yang berkarakter, baik dalam program intrakurikuler maupun ekstrakurikuler terkait pendidikan karakter peserta didik. Pengelolaan manajemen pendidikan karakter yang dijalankan sudah baik terlihat dengan adanya program yang terukur dan kegiatan yang ada dalam lembaga pendidikan mengacu pada kepentingan mutu lulusan melalui implementasi manajemen yang baik. Dari pengelolaan sekolah tersebut, berdampak kepada pendidikan karakter dalam meningkatkan sikap disiplin peserta didik. Namun fakta di lapangan hal tersebut masih belum optimal dan hasilnya belum sesuai dengan yang diharapkan semua pihak. Hal ini di sebabkan adanya beberapa faktor yang di indikasikan sebagai penghambat, baik bersifat internal maupun eksternal. Sehingga lembaga pendidikan terus berbenah diri dalam menyelenggarakan program pendidikan karakter pada peserta didik. Solusi yang dilakukan dalam meningkatkan karakter disiplin peserta didik adalah dengan membangun sinergi semua pihak dalam masyarakat pendidikan untuk membangun budaya disiplin dalam kehidupan Sekolah.

\section{B. Saran}

Adapun saran yang dapat disampaikan berdasarkan hasil penelitian tindakan ini, yaitu Kepala sekolah sebagai manajer harus mampu mendorong fungsi dari guru kelas dan pembimbing ekstrakurikuler menjadi pengawas hal ini bertujuan agar hasil dari kegiatan esktrakurikuler dapat berjalan sesuai dengan tujuan yang diharapkan serta Kepala Sekolah harus menyiapkan segala sarana dan prasarana sesuai dengan kebutuhan dari setiap jenis kegiatan esktrakurikuler sehingga pelaksanaan dari setiap kegiatan ekstrakurikuler berjalan sesuai dengan tujuan yang ingin di capai yang akan berdampak kepada pembentukan pendidikan karakter peserta didik sebagai penunjang dari kegiatan intrakurikuler.

\section{DAFTAR RUJUKAN}

Ali, M. (2007). Manajemen Mutu Pendidikan (dalam) Ali, et.al (2007). Ilmu dan Aplikasi Pendidikan. Bandung: Pedagogiana Press.

Creswell. (2017). Research Design Pendekatan Metode Kualitatif,. Kuantitatif, dan Campuran (Edisi ke4). Yogyakarta: Pustaka Pelajar.

Departemen Pendidikan dan Kebudayaan Republik Indonesia. (2002). Kamus Besar Bahasa Indonesia. Jakarta: Balai Pustaka.
Departemen Pendidikan dan Kebudayaan Republik Indonesia. (1995). Petunjuk Pelaksanaan Kegiatan Ekstrakurikuler. Jakarta: Balai Pustaka.

Kadir (1994), Penuntun Belajar PPKN. Bandung: Ganeca Exact

Kementrian Pendidikan Nasional (2010), Pengembangan Pendidikan Budaya dan Karakter Bangsa. Jakarta: Kementrian Pendidikan Nasional

Lickona, T. (1991), Educating For Character. How Our Schools Can Teach Respect and Responsibility. (Terjemahan) Wamaungo, JA (2012). Mendidik untuk Membentuk Karakter : Bagaimana Sekolah dapat Memberikan Pendidikan tentang Sikap Hormat dan Bertanggung jawab. Jakarta:Bumi Aksara.

Mulyasa, E. (2002). Manajemen Berbasis Sekolah, Konsep, Strategi, dan Implementasi. Bandung: PT. Remaja Rosdakarya.

Mulyasa, E. (2014). Manajemen Pendidikan Karakter. Jakarta: Bumi Aksara.

Nurdin, D. (2009). Manajemen Pendidikan (dalam) Ali, et.al (2009). Ilmu dan Aplikasi Pendidikan: Bagian II: Ilmu Pendidikan Praktis. Bandung: Imtima.

Permendikbud No. 62 Tahun 2014 Tentang Ekstrakurikuler pada Pendidikan Dasar dan Menengah

Permendikbud No. 63 Tahun 2014 Tentang Ekstrakurikuler Pendidikan Kepramukaan

Prijadarminto, S (2004), Disiplin Kiat Menuju Sukses. Jakarta: PT Pratnya Praminto

Requene, KW (2005), Strategi Jitu Membangun Disiplin Anak. Jakarta: Pustaka Raya.

Rohiat. (2009). Manajemen Sekolah: Teori Dasar dan Praktik. Bandung: Refika Aditama.

Sugiyono. (2015). Metode Penelitian Pendidikan (Pendekatan Kuantitatif,. Kualitatif dan R\&D). Bandung : CV. Alfabeta.

Suyadi. (2013). Strategi Pembelajaran Pendidikan Karakter. Bandung: Remaja Rosdakarya.

Syafaruddin. (2002). Manajemen Mutu Terpadu dalam Pendidikan: Konsep, Strategi, dan Aplikasi. Jakarta: Gramedia.

Umaedi. (1999). Panduan Manajemen Pendidikan. Jakarta: Departemen Pendidikan dan Kebudayaan, Direktorat Jenderal Pendidikan 
Dasar dan Menengah, Direktorat Pendidikan Menengah Umum.

Undang-undang No. 3 Tahun 2005 Tentang Sistem Keolahragaan Nasional

Undang-undang No. 12 Tahun 20 Tentang Gerakan Pramuka Pendidikan Kepramukaan
Undang-undang No. 20 Tahun 2003 Tentang Sistem Pendidikan Nasional. Jakarta: Sinar Grafika.

Yaniawati. (2017). Metodologi Penelitian. Bandung: PT. Refika Aditama. 